\title{
Dominant temperament traits among the inmate population: a comparative study
}

\author{
Tony Donchev ${ }^{1 *}$, Hristina Martinova ${ }^{2}$, Vihra Milanova ${ }^{3}$, Vladimir Nakov ${ }^{4}$, Hagop Akiskal ${ }^{5,6}$ \\ From $1^{\text {st }}$ International Congress on Neurobiology and Clinical Psychopharmacology and European \\ Psychiatric Association Conference on Treatment Guidance \\ Thessaloniki, Greece. 19-22 November 2009
}

\section{Background}

Multiple studies document specific personality traits, relatively homogeneous in the structural aspect. We attempt to extrapolate a purely psychological examination approach, applying the clinical conceptualizations of H. Akiskal. This study aims to asses the existence of statistically significant differences between the TEMPSA scale ratings of subjects serving a prison sentence and a control group.

\section{Materials and methods}

We examined a total of 148 patients divided into 2 groups, balanced in quantity and gender: an experimental (prison inmates) $(\mathrm{N}=74)$ and a control group $(\mathrm{N}=74)$. The experimental group included subjects serving sentences in penitentiary institutions within the Republic of Bulgaria's territory. The control group was randomly selected. The TEMPS-A scale was applied to subjects in both groups.

\section{Results}

We found statistically significant differences between the average values in the two groups regarding all scales except for the Hyperthymic temperament.

\section{Conclusions}

The Hyperthimic temperament does not have a specific prognostic value regarding criminal behavior. This temperament can be expected to reflect the degree of adaptation. A question stands as to whether the TEMPS-A scales describe the temperament of premorbid personality or can register changes in the structure of personality as a consequence of substance abuse.

\section{Author details}

${ }^{1}$ Clinic of Psychiatry, Military Medical Academy, Sofia, Bulgaria. ${ }^{2}$ Medical University - Sofia, Sofia, Bulgaria. ${ }^{3} \mathrm{Head}$ of Department of Psychiatry, Medical University - Sofia, Sofia, Bulgaria. ${ }^{4}$ National Center for Public Health Protection, Sofia, Bulgaria. ${ }^{5}$ International Mood Center, University of California at San Diego, California, USA. ${ }^{6}$ The San Diego Veterans Administration Medical Center, USA.

Published: 22 April 2010

\section{References}

1. Roberts A, Min Y, Tianqiang Z, Coid J: Personality disorder, temperament, and childhood adversity: findings from a cohort of prisoners in England and Wales. Journal of Forensic Psychiatry \& Psychology 2008, 19(4).

2. Engström $G$, Persson B, Levander $S$ : Temperament traits in male suicide attempters and violent offenders. European Psychiatry 1999, 14(5).

3. Giotakos O, Vaidakis N, Markianos M, Spandoni P, Christodoulou GN: Temperament and character dimensions of sex offenders in relation to their parental rearing. Sexual and Relationship Therapy 2004, 19(2).

4. Richter J, Krecklow B, Eisemann M: Interrelations between temperament, character, and parental rearing among delinquent adolescents: A crossvalidation. Comprehensive Psychiatry 2002, 43(3).

doi:10.1186/1744-859X-9-S1-S186

Cite this article as: Donchev et al:: Dominant temperament traits among the inmate population: a comparative study. Annals of General Psychiatry 2010 9(Suppl 1):S186.

\footnotetext{
${ }^{1}$ Clinic of Psychiatry, Military Medical Academy, Sofia, Bulgaria
}

Submit your next manuscript to BioMed Central and take full advantage of:

- Convenient online submission

- Thorough peer review

- No space constraints or color figure charges

- Immediate publication on acceptance

- Inclusion in PubMed, CAS, Scopus and Google Scholar

- Research which is freely available for redistribution 